TITLE:

\title{
JUVENILES OF MACROSETELLA GRACILIS (DANA) FROM CLUMPS OF TRICHODESMIUM IN THE VICINITY OF SETO
}

\section{$\operatorname{AUTHOR}(\mathrm{S})$ :}

Tokioka, Takasi; Bieri, Robert

\section{CITATION:}

Tokioka, Takasi ... [et al]. JUVENILES OF MACROSETELLA GRACILIS (DANA) FROM CLUMPS OF TRICHODESMIUM IN THE VICINITY OF SETO. PUBLICATIONS OF THE SETO MARINE BIOLOGICAL LABORATORY 1966, 14(3): 177-184

\section{ISSUE DATE:}

1966-07-20

URL:

http://hdl.handle.net/2433/175440

RIGHT: 


\title{
JUVENILES OF MACROSETELLA GRACILIS (DANA) FROM CLUMPS OF TRICHODESMIUM IN THE VICINITY OF SETO ${ }^{1)}$
}

\author{
TAKASI TOKIOKA
}

Seto Marine Biological Laboratory

and

ROBERT BIERI

Antioch College, Ohio, U.S.A.

With Plates V-VI and 4 Text-figures

The role of Trichodesmium in the ecology of the sea, especially with regard to its contribution in nitrogen fixation and utilization, was briefly discussed by the participants of the First International Interdisciplinary Conference on Marine Biology (RILEY 1963). At that time, no animal was known to directly utilize this plant. Since then, however, BJöRnBerg (1965) has shown that Macrosetella gracilis (DANA) spends its larval stages among the filaments of clumps of Trichodesmium. The larval stages are in a strict sense non-pelagic, as is the usual case in the bottom-living harpacticoid copepods. As BJöRNBERg pointed out, Macrosetellla may be an important second link between Trichodesmium and other animals in the tropical pelagic biotope. Bowman and Lancaster (1965) noted that in a bloom of Trichodesmium in the Tonga Islands the only animals found in the plankton samples were a few harpacticoid and cyclopoid copepods, belonging to non-pelagic genera. This seems to suggest that the observations made by BJörnberg in the Caribbean Sea and the South Atlantic off Brazil may be repeated again in the warm water regions of the Pacific. With these reports in mind, we have noticed the occurrences of Trichodesmium in the vicinity of Seto.

On October 2, 1965, BIERI collected many clumps of Trichodesmium while observing neuston in shallow water off the north beach of the laboratory. One clump of Trichodesmium was found harbouring one nauplius and another clump had 5 nauplii in it. On October 9, three more clumps of Trichodesmium were collected at the same place, two of them each had one copepodite. On October 13, five copepodites were collected from clumps of Trichodesmium gathered from the same area. On October

1) Contributions from the Seto Marine Biological Laboratory, No. 456.

Publ. Seto Mar. Biol. Lab., XIV (3), 177-184, 1966. (Article 14) 
18, clumps of Trichodesmium were collected with a neuston net, Booby III, (BIERI and Newbury, 1966) from the upper $10 \mathrm{~cm}$ of water near the lighthouse at the mouth of Tanabe Bay. The clumps of Trichodesmium observed in this region apparently belong to T.erythraeum EHRENBERG, although there seem to be several different types of clumps. The blue green alga occurred at a concentration of at least 65 clumps per cubic meter of water. A number of nauplii were found in these clumps at a concentration of about 14 nauplii per cubic meter of water. This time about 30 nauplii were picked up from the clumps.

The nauplii occurred in groups of one to six on a clump of Trichodesmium and some were found attached to a single filament of the alga. They were found clinging to the filaments even in a preserved state in formalin. Generally nauplii of the earlier stages are found more crowded on a clump of Trichodesmium than the later stages, only one or two specimens of the last nauplius were found in a single preserved clump of the alga. On the other hand, the copepodites seem to be wholly detached from the clumps at fixation. They can only be isolated from the living clumps.

Dr. K. Furuhashi of the Oceanographical Section of the Japan Meteorological Agency kindly offered us photographs of a copepodite found in a plankton sample taken in a dense bloom of Trichodesmium near the southern "fixed point of observation" (T-point or TANGO, $29^{\circ} 00^{\prime} \mathrm{N} \times 135^{\circ} 00^{\prime} \mathrm{E}$ ) in the western North Pacific in May, 1963. This copepodite is $670 \mu$ in length and conforms with the second copepodite stage of BJöRNBERG in having three pairs of well developed swimming legs. He mentions in his letter to Toкıoka that he found only this copepodite and a single nauplius in the plankton sample. The material, thus collected, seemingly comprises all of the naupliar stages, but only the first copepodid stage.

The specimens were examined carefully by Tokıoka and their morphological aspects compared with the descriptions and figures given by BJörNBERG. It was then found that we were treating the same species observed by BJörnBERG in the Caribbean Sea and South Atlantic, namely, Macrosetella gracilis (DANA). The general features of the juveniles collected in the vicinity of Seto conform well with those given by BJörnberg. However, one more nauplius stage is suggested between the second and the third stages described by BJörnberg. Further, there are some minute or delicate structrures which were neither referred to nor shown by BJörNBERG. The following descriptions are made to record these points clearly.

\section{Nauplius stages I-V}

1) The first to third nauplii (Text-fig. 1 A-C, Text-fig. 2 1,2): Antennule and antenna retain the quite similar structure throughout these three stages. The antennule is non-segmented and bears one shorter and two longer setae at the distal end and another seta near the middle of the anterior margin. The antenna is three-segmented. The basal segment has a stout spine at the inner basal portion, which extends 


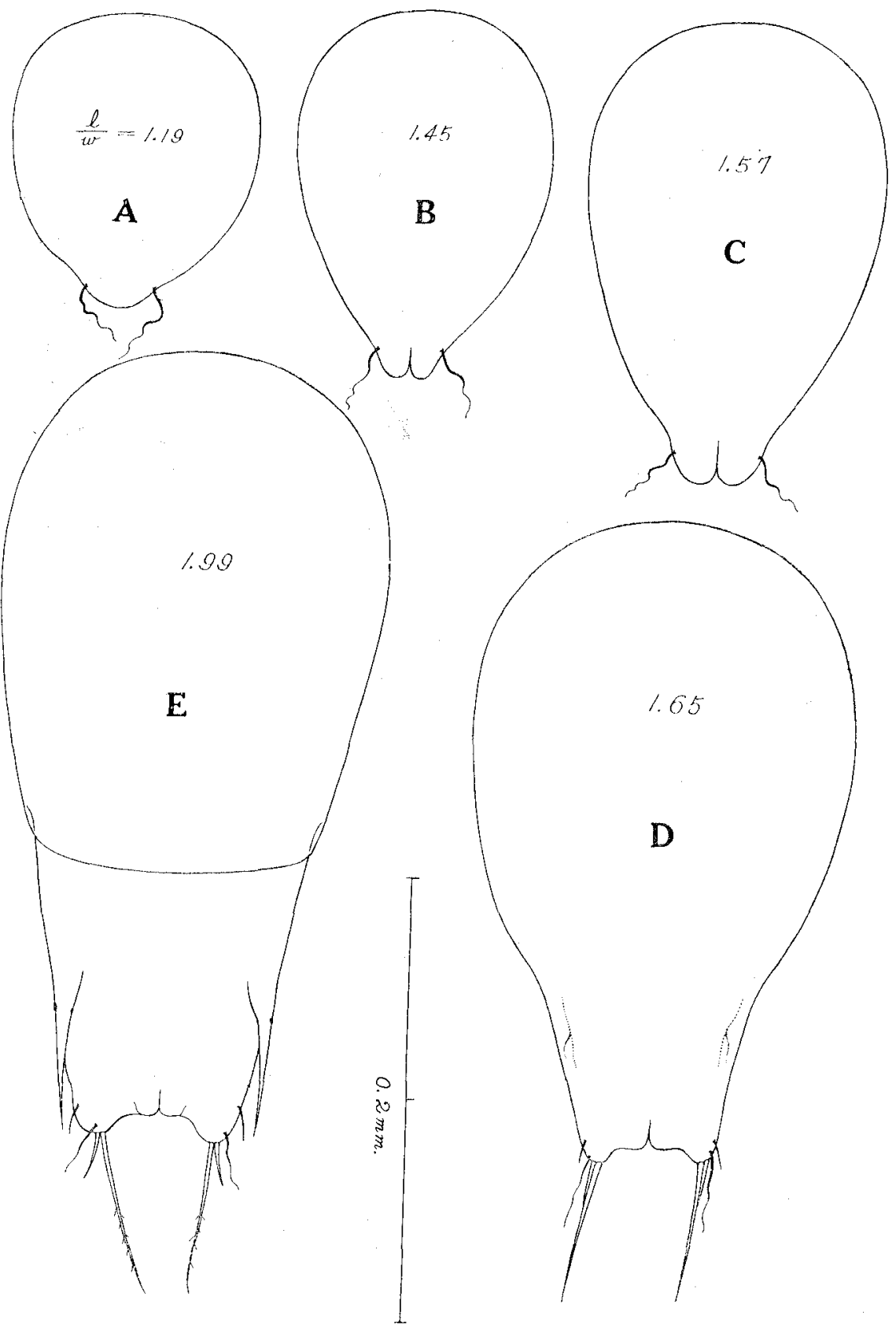

Text-fig. 1. Macrosetella gracilis (DANA). Body outline in five nauplius stages, with the details of the setal armature at the caudal end. A-the first, B-the second, $\mathrm{C}$ - the third, D-the fourth, and E-the fifth nauplius, ventral. 1--length, w-width. 


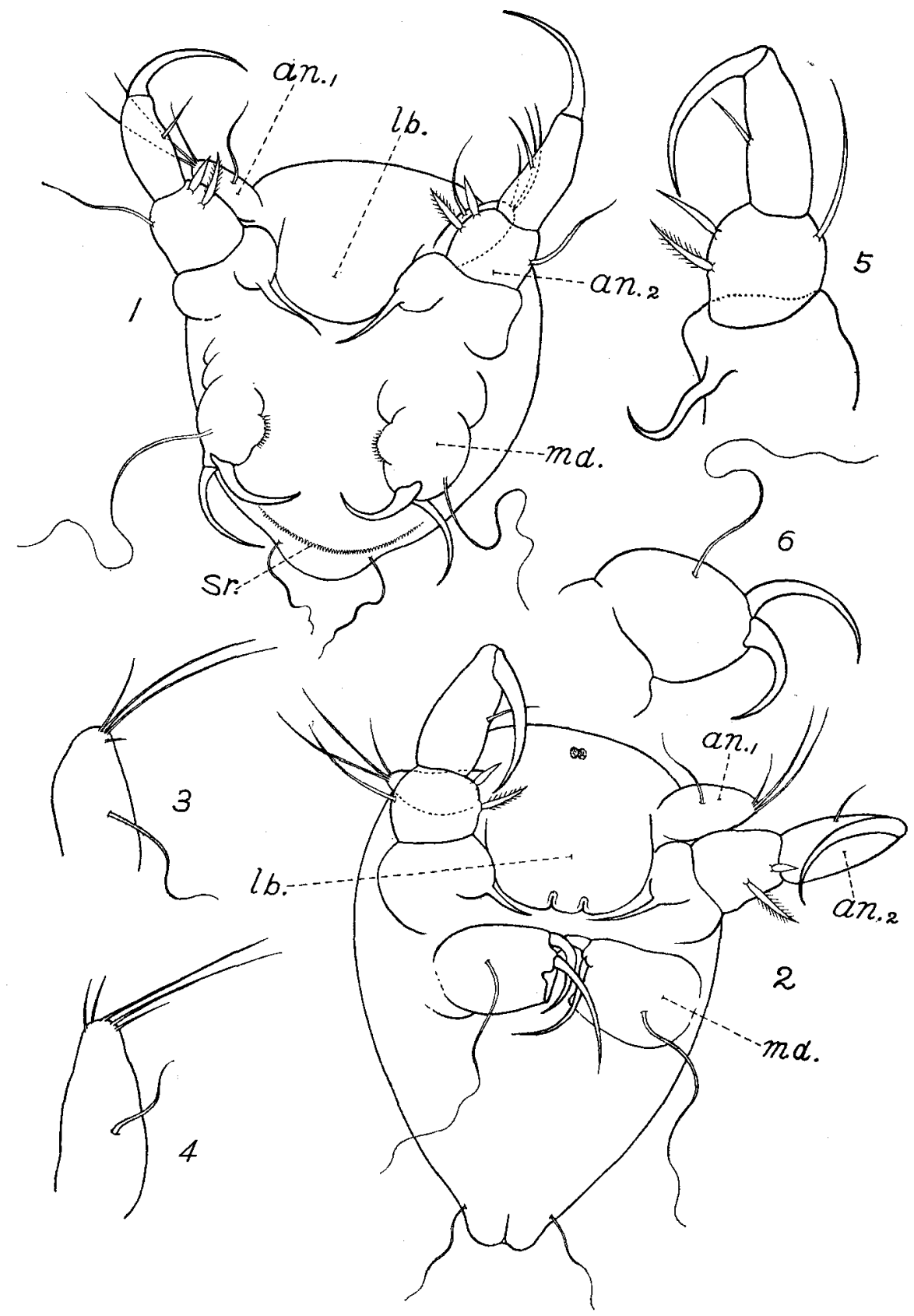

Text-fig. 2. Macrosetella gracilis (DANA). The first (1) and the second (2) nauplii, ventral; and some appendages of the fourth and the fifth nauplii. 3-Antennule of the fourth nauplius. 4-Antennule of the fifth nauplius. 5-Antenna of the fourth nauplius. 6 -Mandible of the fourth nauplius. $\times 415$.

$a n_{1}$-antennule, an.2-antenna, $l b$. -labrum, $m d$. - mandible, sr.-serrated crest. 
towards the midventral line of the body along the postero-lateral border of the labrum. The middle segment has two short but stout setae in the distal half of the inner edge and a slender seta near the middle of the outer edge. The proximal seta on the inner edge is plumose. The distal segment ends in a strong claw and has a seta at the middle of the inner edge. The mandible is a roundish appendage located on a mound. It has a pair of claws at the distal end, the anterior claw is a little shorter but stouter than the posterior, and two claws are directed differently in a preserved state. A long seta is found near the middle of the outer edge, the tip of the seta is tapering into a long filament. A pair of filamentous setae are present near the caudal end of the body. Rarely two setae may occur on one side.

1st stage - The body is nearly roundish in outline, about $130 \mu$ in length and length/ width ratio is 1.19 in a mearured specimen. The median notch at the caudal end is not yet defined. A finely serrated crest (sr. in Text-fig. 21 ) is present on the ventral surface near the caudal end of the body. A part of the inner edge of the mandible is provided with a series of hairy spinules.

2nd and 3rd stages-The body is a little elongate, about $165 \mu$ in length and with a length/width ratio of 1.45 in the second, and about $210 \mu$ in length and with a length / width ratio of 1.57 in the third stage. The median notch at the caudal end is well defined and the serrated crest on the ventral surface disappears. The row of hairy spinules on the inner edge of the mandible disappears, too. The distal end of the mandible assumes a truncate edge and becomes very stout as seen in $m d$. in Text-fig. 22 . A pair of notches at the middle of the posterior margin of the labrum becomes distinct in the second stage.

2) The fourth stage (Text-fig. $1 \mathrm{D}$, Text-fig. $23,5,6$ ): The body is about $280 \mu$ long, the length/width ratio is 1.65 in an examined specimen. The caudal furca appears at this stage. Two stout bristles, one long and one short, a hair-like seta and a short seta appear at the end of each furca. A short seta is added at the tip of the antennule. The distal end of the mandible becomes rounded as in the first nauplius. 3) The fifth stage (Pl. V, Text-fig. $1 \mathrm{E}$, Text-fig. 24 ): The body is $345 \mu$ in length, the length/width ratio is 1.99 in a measured specimen. The body is now clearly twosegmented, the posterior edge of the first segment reaches a little posterior to the middle of the body. A pair of stout but very simple appendages are found on the posterior half of the body, each on the ventro-lateral edge. The shorter stout bristle at the end of the caudal furca is now liberated from the side of the longer one which is now plumose. The antennule has two long and three short setae at the distal end.

\section{The first copepodid stages}

$$
\text { (Pl. VI, Text-figs. } 3 \text { and 4) }
$$

The body is about $450 \mu$ in length excluding the caudal furcae. Behind the $200 \mu$ long carapace, five free segments are defined clearly. The anterior end of the 
carapace is protruded into a short rostrum gently bending down ventrally. The first free segment is exposed only along its posterior border and the last segment is the longest. Each caudal furca is furnished with two unequal terminal plumose setae, two simple setae and two spinules. The inner plumose seta is up to $280 \mu$

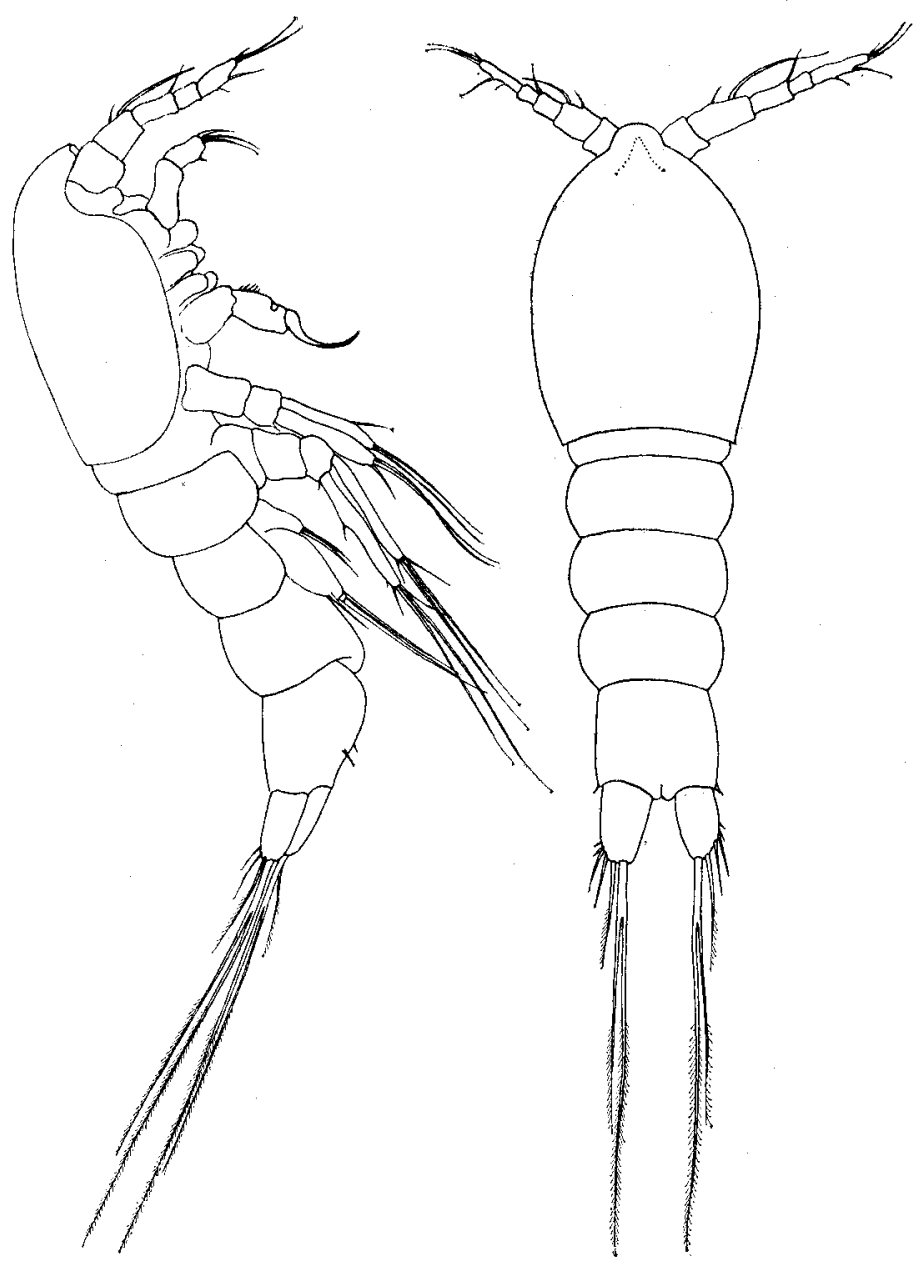

Text-fig. 3. Macrosetella gracilis (DANA) The first copepodid stage. Left-right side, Right-dorsal view. $\times 150$.

in length and bifurcate. A spinule is present at the postero-lateral corner of the last segment and a pair of spinules near the centre of the ventral surface of the same segment. The antennule consists of four proximal segments and an elongate distal segment which seems to be divisible further into three segments. It is armed only with simple setae which are distributed as seen in Text-fig. 41. The antenna 
(Text-fig. 42) is reduced to a two-segmented short appendage. The distal segment is smaller than the proximal one and furnished with two long and a short setae and a spine at the distal end and with a spine and two spinules near the middle of the

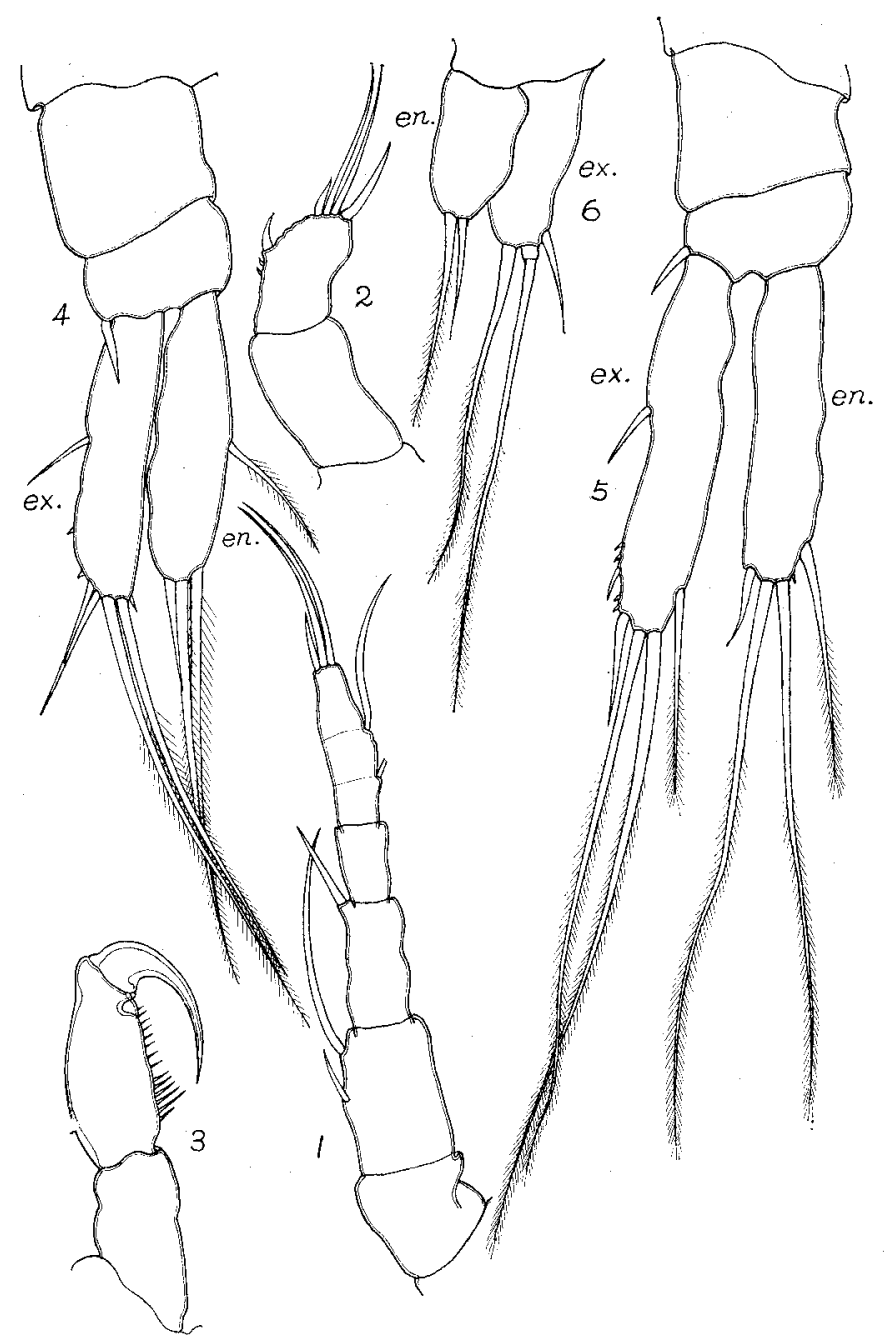

Text-fig. 4. Macrosetella gracilis (DANA). Appendages of the first copepodite. $\times 330$.

1-antennule, 2-antenna, 3 -maxilliped, 4 - the first swimming leg, 5-the second swimming leg, 6-the third swimming leg. en.- endopodite, ex.- exopodite.

posterior edge. The maxilliped (Text-fig. 43 ) is two-segmented, the distal segment ends in a strong hook and is furnished with a series of bristles along the inner edge. Several proximal bristles are longer than distal ones. Three pairs of swimming legs 
are present, although the third pair is still rudimentary. The first and the second legs consist each of the two-segmented protopodite and non-segmented endopodite and exopodite. The exopodite is a little longer than the endopodite in all legs. The setal armature of these legs is shown exactly in Text-fig. 44,5. The second pair is a little more developed than the first and probably plays the principal role in swimming as seen in Pl. VI 6. The third leg (Text-fig. 46) consists of non-segmented endopodite and exopodite situated on a mound. The endopodite has a plumose seta and a simple seta at the distal end, while the exopodite has two plumose setae and a simple one at the end. The external plumose seta of the exopodite is unique in having a small proximal mound.

\section{REFERENCES}

Bieri, R. and T.K. Newbury (1966): BOOBY II, a quantitative neuston sampler for use from small boats. Publ. Seto Mar. Biol. Lab., Vol. XIII, No. 5, pp. 405-410, 4 text-figs.

BjöRnBERG, T. K. S. (1965): Obseravations on the development and the biology of the Miracidae Dana (Copepoda: Crustacea). Bull. Mar. Sci., Vol. 15, No. 2, pp. 512-520, 8 text-figs.

Bowman, T. E. and L. J. Lancaster (1965): A bloom of the planktonic blue-green alga, Trichodesmium erythraeum, in the Tonga Islands. Limnology and Oceanography, Vol. 10, No. 2, pp. 291-293.

Riley, G.E. (Ed.) (1963): Marine Biology I, A. I. B. S., Washington D. C., 286 pp.

\section{EXPLANATION OF PLATES V AND VI}

\section{Plate V}

The fifth nauplius of Macrosetella gracilis (DANA) clinging to the filaments of Trichodesmium, collected on October 2, 1965. (Through the courtesy of N. H. K.)

1-A clump of Trichodesmium harbouring a nauplius.

2-Left side of the body.

3, 4-Right ventral side. A faint striation dividing the body into the anterior and posterior segments is seen in Fig. 3.

\section{Plate VI}

The first copepodite of Macrosetella gracilis (DANA) collected on October 13, 1965. (BIERI photo)

5-A clump of Trichodesmium harbouring a copepodite (c).

6-Dorsal aspect of a copepodite.

7-Two copepodites from the right side. 
Publ. Seto Mar. Biol. Lab., XIV (3), 1966. Plate V
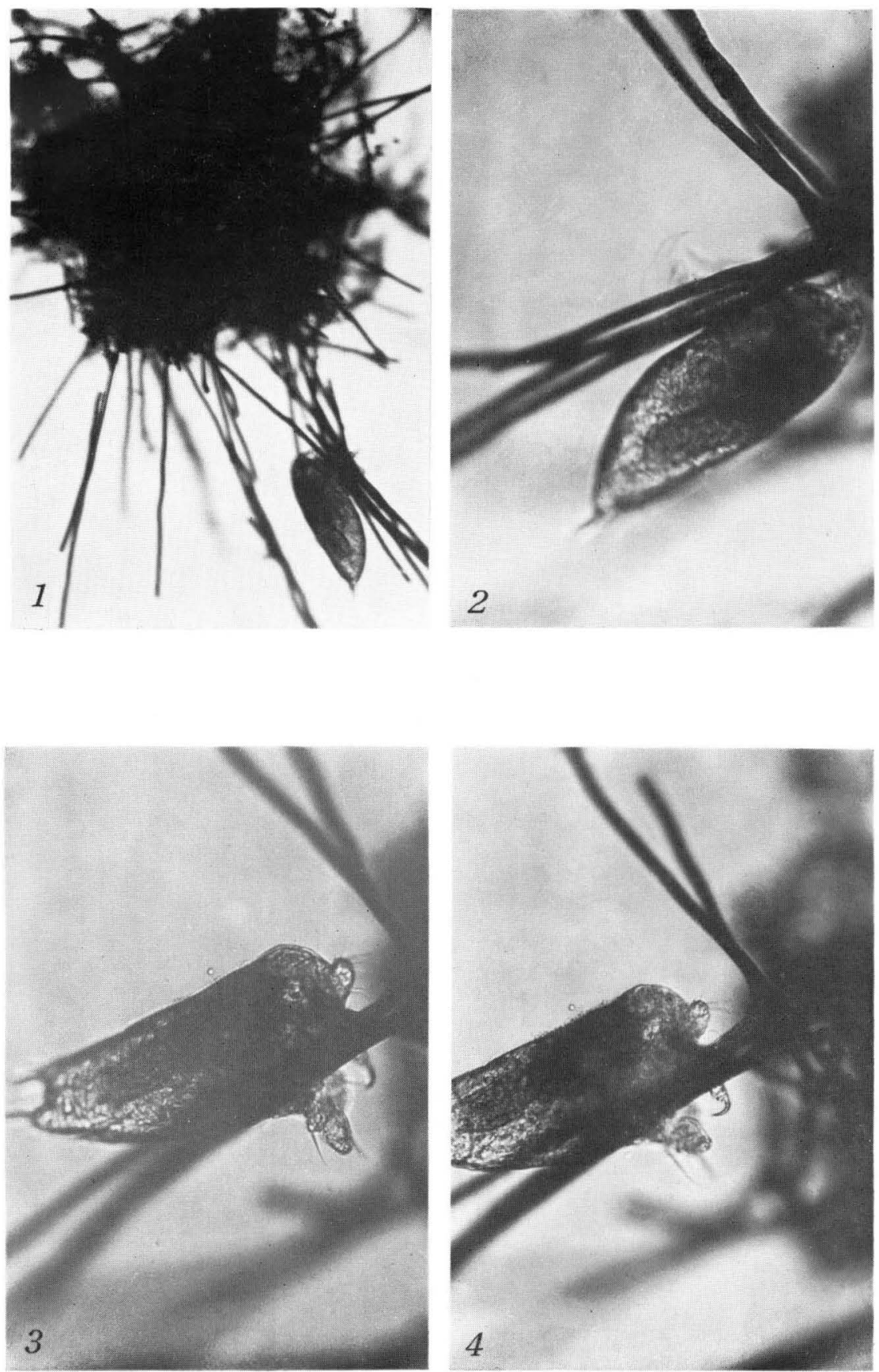

T. TOKIOKA and R. BIERI: Macrosetella Juveniles from Trichodesmium Clumps. 
Publ. Seto Mar. Biol. Lab., XIV (3), 1966. PLATE VI
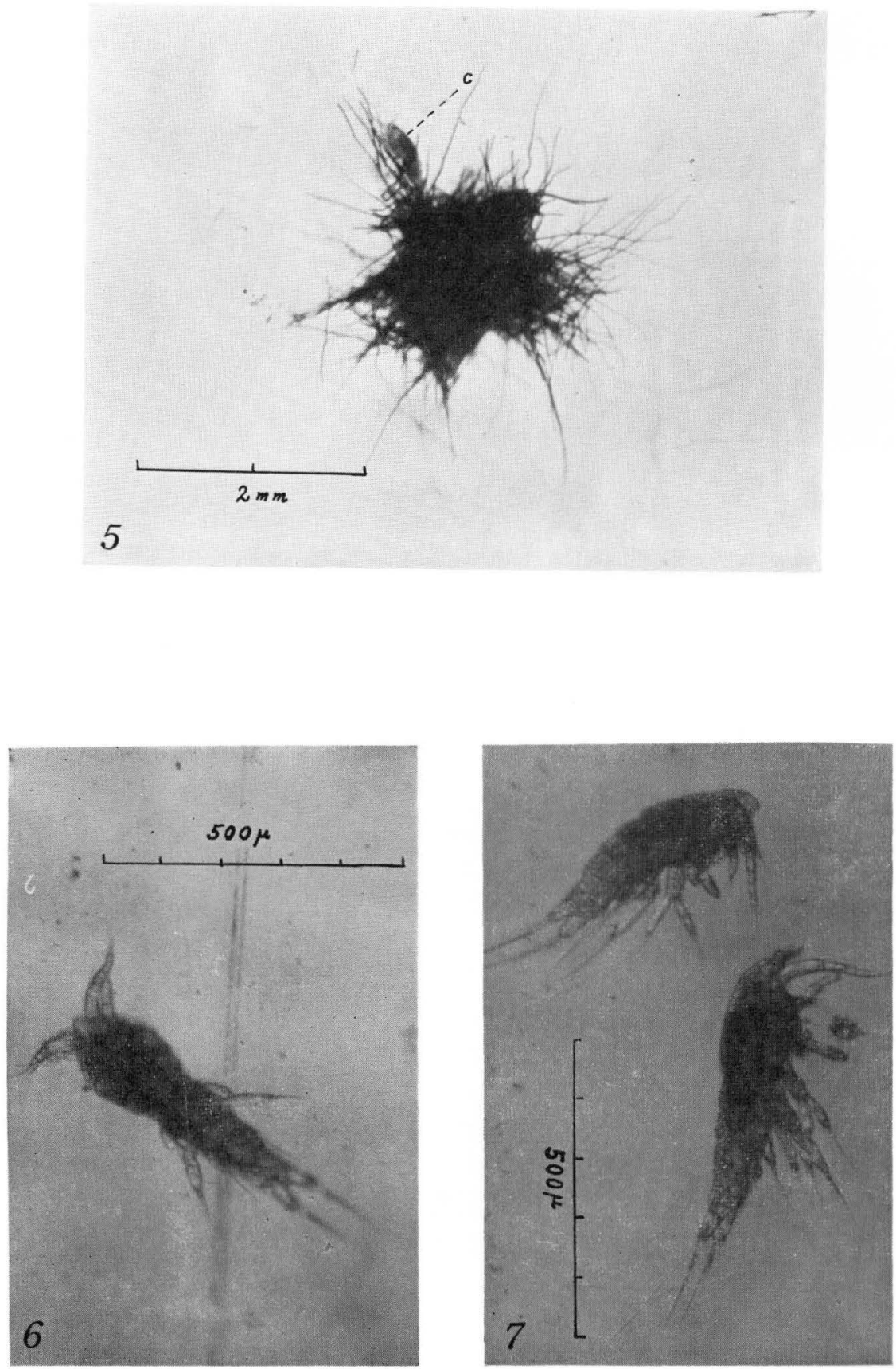

T. TokiokA and R. BIERI: Macrosetella Juveniles from Trichodesmium Clumps. 